\title{
Amidinate Ligands in Zinc coordination sphere: Synthesis and structural diversity
}

\author{
SRINIVAS ANGA, INDRANI BANERJEE and TARUN K PANDA* \\ Department of Chemistry, Indian Institute of Technology Hyderabad, Kandi 502 285, \\ Sangareddy, Telangana, India \\ e-mail: tpanda@iith.ac.in
}

MS received 25 February 2016; revised 3 April 2016; accepted 8 April 2016

\begin{abstract}
A one-pot reaction involving neosilyllithium and three different carbodiimides $(\mathrm{RN}=\mathrm{C}=\mathrm{NR}, \mathrm{R}=$ cyclohexyl, isopropyl and tert-butyl) in diethyl ether, followed by the addition of anhydrous $\mathrm{ZnCl}_{2}$, afforded, in high yield, corresponding homoleptic zinc amidinate complexes having the molecular formulae $\left[\mathrm{Zn}\left\{\mathrm{CyN}=\mathrm{C}\left(\mathrm{CH}_{2} \mathrm{SiMe}_{3}\right) \mathrm{NCy}\right\}_{2}\right](\mathbf{1}),\left[\mathrm{Zn}\left\{{ }^{i} \mathrm{PrN}=\mathrm{C}\left(\mathrm{CH}_{2} \mathrm{SiMe}_{3}\right) \mathrm{N}^{i} \mathrm{Pr}\right\}_{2}\right]$ (2) and $\left[\mathrm{Zn}\left\{{ }^{t} \mathrm{BuN}=\mathrm{C}\left(\mathrm{CH}_{2} \mathrm{SiMe}\right)_{3}\right)\right.$ $\mathrm{N}^{t} \mathrm{Bu}_{2}$ ] (3), respectively, and amidinato moieties in the zinc coordination sphere. Solid state structures of complexes 1-3 are reported thereafter - all the three complexes are isostructural, and each of them consists of two four-membered metallacycles.
\end{abstract}

Keywords. Zinc; carbodiimides; amidinate; alkyl migration.

\section{Introduction}

Zinc is biologically one of the most important metal and an adult human body contains approximately $2 \mathrm{~g}$ of it in the form of active site in various enzymes. ${ }^{1}$ The remarkable discovery by Frankland of the first organometallic compound 'diethyl zinc' from ethyl iodide and zinc metal unearthed the potential of application of organo-zinc compounds in the development of synthetic organic chemistry. ${ }^{2,3}$ There has been significant interest in zinc chemistry in the last decade. Several systems including $N, N^{\prime}$-chelating organic ligands such as $\beta$ diketiminate, ${ }^{4}$ guanidinate ${ }^{5}$ and amidinate anions ${ }^{6}$ have been investigated intensely in both main group and transition metal chemistry. ${ }^{7}$ It has been proven that steric and electronic properties of these $N, N^{\prime}$-chelating substituents can be easily modified by using the different organic substituents $\mathrm{R}$ and $\mathrm{R}$ ' present on the nitrogen atom, thus allowing fine-tuning of the chemical properties of the resulting metal complexes. Consequently, a large variety of low-coordinate organometallic compounds in low oxidation states have been synthesized and structurally characterized. ${ }^{8}$

In case of organozinc chemistry, interest has been focused on $\beta$-diketiminato complexes of the general

\footnotetext{
*For correspondence

This work is dedicated to Prof. Dr. Peter W. Roesky on the occasion of his $49^{\text {th }}$ birth anniversary
}

type $\mathrm{LZnR}(\mathrm{L}=\beta \text {-diketiminate })^{9}$ which were shown to be active catalysts in the metal catalyzed ring-opening polymerization (ROP) of cyclic esters - in particular lactides, ${ }^{10}$ and in copolymerization of $\mathrm{CO}_{2}$ and epoxides, respectively. ${ }^{11}$ Moreover, low-valent organozinc compounds of the general type LZn-ZnL containing a direct $\mathrm{Zn}-\mathrm{Zn}$ bond, which were initially prepared by Carmona et al., ${ }^{12}$ can be stabilized by using chelating organic substituents, $\left(\mathrm{L}-\left[\left\{\left(2,6-{ }^{i} \mathrm{Pr}_{2} \mathrm{C}_{6} \mathrm{H}_{3}\right) \mathrm{N}(\mathrm{Me}) \mathrm{C}\right\}_{2}\right.\right.$ $\mathrm{CH}],{ }^{13}$ 1,2-Bis[(2,6-diisopropylphenyl)imino]acenaphthene). ${ }^{14}$ There are several reports on zinc guanidinate and amidinate complexes, and their applications in various polymerization of cyclic esters and copolymerization reactions, and in the materials science (i.e., CVD precursors)..$^{15}$ Very recently, zinc(II) was used as competent metal ion to prepare one and two dimensional coordination polymers using various flexible ligands. ${ }^{16}$ In our ongoing work too, we are working with zinc, supported by various mixed $\mathrm{N}-/ \mathrm{O}-$ donors ${ }^{17}$ and $\mathrm{NHC}$ based ligands. ${ }^{18}$ However, to the best of our knowledge, there are no reports on any direct synthesis of zinc amidinate complexes while using one-pot reaction with alkyl migration to the carbodiimide backbone to generate anionic amidinate moiety.

Herein, we report the syntheses of homoleptic zinc amidinate complexes having the molecular formulas $\left[\mathrm{Zn}\left\{\mathrm{CyN}=\mathrm{C}\left(\mathrm{CH}_{2} \mathrm{SiMe}_{3}\right) \mathrm{NCy}\right\}_{2}\right] \quad(\mathbf{1}), \quad\left[\mathrm{Zn}\left\{{ }^{i} \mathrm{PrN}=\right.\right.$ $\left.\left.\mathrm{C}\left(\mathrm{CH}_{2} \mathrm{SiMe}_{3}\right) \mathrm{N}^{i} \mathrm{Pr}\right\}_{2}\right](2)$ and $\left[\mathrm{Zn}\left\{{ }^{t} \mathrm{BuN}=\mathrm{C}\left(\mathrm{CH}_{2} \mathrm{SiMe}_{3}\right)\right.\right.$ $\left.\mathrm{N}^{t} \mathrm{Bu}\right\}_{2}$ ] (3). Full characterization and structural studies of all the complexes are also presented. 


\section{Experimental}

\subsection{General Information}

All manipulations of air-sensitive materials were performed with the rigorous exclusion of oxygen and moisture in flame dried Schlenk-type glassware, either on a dual manifold Schlenk line interfaced to a high vacuum $\left(10^{-4}\right.$ torr) line, or in an argon-filled M. Braun glove box. Diethyl ether was pre-dried over $\mathrm{Na}$ wire and distilled under nitrogen from sodium and benzophenone ketyl prior to use. Hydrocarbon solvent (n-pentane) was distilled under nitrogen from $\mathrm{LiAlH}_{4}$ and stored in the glovebox. ${ }^{1} \mathrm{H}$ NMR (400 MHz) and ${ }^{13} \mathrm{C}\left\{{ }^{1} \mathrm{H}\right\}$ NMR spectra were recorded on a Bruker Avance III-400 spectrometer. Elemental analyses were performed on a Bruker Euro EA at the Indian Institute of Technology Hyderabad. Carbodiimides $(\mathrm{RN}=\mathrm{C}=\mathrm{NR} ; \mathrm{R}=\mathrm{Cy}$, ${ }^{i} \mathrm{Pr},{ }^{t} \mathrm{Bu}$ ) were purchased from Sigma Aldrich and used as received. $\mathrm{LiCH}_{2} \mathrm{SiMe}_{3}$ were prepared according to the procedure described in the literature. ${ }^{19}$ Anhydrous $\mathrm{ZnCl}_{2}$ and NMR solvent $\mathrm{C}_{6} \mathrm{D}_{6}$ were purchased from Sigma Aldrich. $\mathrm{C}_{6} \mathrm{D}_{6}$ was dried under $\mathrm{Na} / \mathrm{K}$ alloy prior to use.

\subsection{Synthesis of $\left[\mathrm{Zn}\left\{\mathrm{CyN}=\mathrm{C}\left(\mathrm{CH}_{2} \mathrm{SiMe}_{3}\right) \mathrm{NCy}_{2}\right](\mathbf{1})\right.$}

To a solution of $\mathrm{N}, \mathrm{N}^{\prime}$-dicyclohexylcarbodiimide (DCC) (206 mg, $1 \mathrm{mmol}$ ) in $5 \mathrm{~mL} \mathrm{Et}_{2} \mathrm{O}$, a pre-cooled etheral solution $(5 \mathrm{~mL})$ of $\mathrm{LiCH}_{2} \mathrm{SiMe}_{3}(95 \mathrm{mg}, 1 \mathrm{mmol})$ was added at ambient temperature $\left(25^{\circ} \mathrm{C}\right)$ and stirred for 2 h. To this mixture, anhydrous $\mathrm{ZnCl}_{2}(68 \mathrm{mg}, 0.5 \mathrm{mmol})$ was directly added, and the resultant solution was stirred for another $12 \mathrm{~h}$ at ambient temperature $\left(25^{\circ} \mathrm{C}\right)$. Thereafter, $\mathrm{LiCl}$ was removed by filtration, and the filtrate was evaporated to dryness under reduced pressure resulting in a white solid which was re-crystallized from $\mathrm{Et}_{2} \mathrm{O}$ at $-35^{\circ} \mathrm{C}$ which therefore yielded colorless crystals after one day. Yield $295 \mathrm{mg}(90 \%) .{ }^{1} \mathrm{H}$ NMR $\left(400 \mathrm{MHz}, \mathrm{C}_{6} \mathrm{D}_{6}, 25^{\circ} \mathrm{C}\right): \delta=3.9(\mathrm{~m}, 4 \mathrm{H}, \mathrm{Cy}-H), 1.91$ (s, 4H, $\mathrm{CH}_{2}-\mathrm{SiMe}_{3}$ ), 1.84 (m, 16H, Cy- $\mathrm{CH}_{2}$ ), 1.56 (m, $4 \mathrm{H}, \mathrm{Cy}-\mathrm{CH} 2), 1.40$ (m, 20H, Cy- $\left.\mathrm{CH}_{2}\right), 0.18$ (s, 18H, $\left.\mathrm{Si} M e_{3}\right) \mathrm{ppm} ;{ }^{13} \mathrm{C}\left\{{ }^{1} \mathrm{H}\right\}$ NMR $\left(100 \mathrm{MHz}, \mathrm{C}_{6} \mathrm{D}_{6}\right): \delta=$ $171.4(\mathrm{~N}=C-\mathrm{N}), 53.5(\mathrm{Cy}-\mathrm{C}-\mathrm{N}), 37.2\left(\mathrm{Cy}-\mathrm{CH}_{2}\right)$, $26.6\left(\mathrm{Cy}-\mathrm{CH}_{2}\right), 25.5\left(\mathrm{Cy}-\mathrm{CH}_{2}\right), 16.4\left(\mathrm{CH}_{2} \mathrm{SiMe}_{3}\right)$, $\left.-0.3(\mathrm{SiMe})_{3}\right)$ ppm. Elemental Analysis: $\mathrm{C}_{34} \mathrm{H}_{66} \mathrm{~N}_{4} \mathrm{Si}_{2} \mathrm{Zn}$ (657.48): Calcd. (\%): C 62.59, H 10.20, N 8.59. Found (\%): C 62.34, H 9.93, N 8.29.

\subsection{Synthesis of $\left[\mathrm{Zn}\left\{{ }^{i} \mathrm{PrN}=\mathrm{C}\left(\mathrm{CH}_{2} \mathrm{SiMe}_{3}\right) \mathrm{N}^{i} \mathrm{Pr}\right\}_{2}\right](\mathbf{2})$}

To a solution of $\mathrm{N}, \mathrm{N}^{\prime}$-diisopropylcarbodiimide (126 mg, $1 \mathrm{mmol}$ ) in $5 \mathrm{~mL} \mathrm{Et}_{2} \mathrm{O}$, a pre-cooled etheral solution,
(5 mL) $\mathrm{LiCH}_{2} \mathrm{SiMe}_{3}$ (95 mg, $1 \mathrm{mmol}$ ), was added at ambient temperature and stirred for $2 \mathrm{~h}$. To this solution, anhydrous $\mathrm{ZnCl}_{2}$ (68 mg, $0.5 \mathrm{mmol}$ ) was directly added and the solution was allowed to stir for $12 \mathrm{~h}$ at ambient temperature $\left(25^{\circ} \mathrm{C}\right)$. $\mathrm{LiCl}$ was removed by filtration, and the filtrate was evaporated to dryness under reduced pressure. The resultant white solid was re-crystallized from $\mathrm{Et}_{2} \mathrm{O}$ at $-35^{\circ} \mathrm{C}$ thus yielding colorless crystals after one day. Yield $226 \mathrm{mg}(92 \%) .{ }^{1} \mathrm{H}$ NMR $(400 \mathrm{MHz}$, $\left.\mathrm{C}_{6} \mathrm{D}_{6}, 25^{\circ} \mathrm{C}\right): \delta=3.5(\mathrm{~m}, 4 \mathrm{H}, \mathrm{CH}), 1.85\left(\mathrm{~s}, 4 \mathrm{H}, \mathrm{CH}_{2}-\right.$ $\left.\mathrm{SiMe}_{3}\right), 1.19\left(\mathrm{~d}, J=6.2 \mathrm{~Hz}, 24 \mathrm{H}, \mathrm{CH}_{3}\right), 0.14(\mathrm{~s}, 18 \mathrm{H}$, $\left.\mathrm{Si} e_{3}\right) \mathrm{ppm} ;{ }^{13} \mathrm{C}\left\{{ }^{1} \mathrm{H}\right\} \mathrm{NMR}\left(100 \mathrm{MHz}, \mathrm{C}_{6} \mathrm{D}_{6}, 25^{\circ} \mathrm{C}\right)$ : $\delta=173.3(\mathrm{~N}=C-\mathrm{N}), 45.7\left(\mathrm{Me}_{2} C \mathrm{H}-\mathrm{N}\right), 26.6$ $\left(\mathrm{CH}_{3}\right), 16.2\left(\mathrm{CH}_{2}-\mathrm{SiMe}_{3}\right),-0.4(\mathrm{SiMe}) \mathrm{ppm}$. Elemental Analysis: $\mathrm{C}_{22} \mathrm{H}_{50} \mathrm{~N}_{4} \mathrm{Si}_{2} \mathrm{Zn}$ (492.91): Calcd. (\%): C 53.68, H 10.24, N 11.38. Found (\%): C 53.43, H 9.92, N 11.02 .

\subsection{Synthesis of $\left[\mathrm{Zn}\left\{{ }^{t} \mathrm{BuN}=\mathrm{C}\left(\mathrm{CH}_{2} \mathrm{SiMe}_{3}\right) \mathrm{N}^{t} \mathrm{Bu}\right\}_{2}\right](3)$}

To a solution of $\mathrm{N}, \mathrm{N}^{\prime}$-di-tert-butylcarbodiimide (154 $\mathrm{mg}, 1 \mathrm{mmol}$ ) in $5 \mathrm{~mL} \mathrm{Et}_{2} \mathrm{O}$, a pre-cooled etheral solution $(5 \mathrm{~mL})$ of $\mathrm{LiCH}_{2} \mathrm{SiMe}_{3}(95 \mathrm{mg}, 1 \mathrm{mmol})$ in $\mathrm{Et}_{2} \mathrm{O}(5 \mathrm{~mL})$ was added at ambient temperature $\left(25^{\circ} \mathrm{C}\right)$ and stirred for $2 \mathrm{~h}$. To this solution, anhydrous $\mathrm{ZnCl}_{2}$ (68 $\mathrm{mg}, 0.5 \mathrm{mmol}$ ) was directly added and the mixture was allowed to stir for another $12 \mathrm{~h}$ at ambient temperature. $\mathrm{LiCl}$ was removed by filtration and the filtrate was evaporated to dryness under reduced pressure resulting in a white solid which was recrystallized from $\mathrm{Et}_{2} \mathrm{O}$ at $-35^{\circ} \mathrm{C}$ to give colorless crystals after one day. Yield $230 \mathrm{mg}(84 \%) .{ }^{1} \mathrm{H}$ NMR $\left(400 \mathrm{MHz}, \mathrm{C}_{6} \mathrm{D}_{6}, 25^{\circ} \mathrm{C}\right)$ : $\delta=2.2\left(\mathrm{~s}, 4 \mathrm{H}, \mathrm{CH}_{2}-\mathrm{SiMe}_{3}\right), 1.38\left(\mathrm{~s}, 36 \mathrm{H}, \mathrm{CH}_{3}\right), 0.24$ (s, $\left.18 \mathrm{H}, \mathrm{Si} M e_{3}\right) \mathrm{ppm} ;{ }^{13} \mathrm{C}\left\{{ }^{1} \mathrm{H}\right\} \mathrm{NMR}\left(100 \mathrm{MHz}, \mathrm{C}_{6} \mathrm{D}_{6}\right)$ : $\delta=171.9(\mathrm{~N}=C-\mathrm{N}), 50.6\left(\mathrm{Me}_{3} C-\mathrm{N}\right), 33.6\left(C_{3}\right), 20.9$ $\left.\left(\mathrm{CH}_{2}-\mathrm{SiMe}_{3}\right), 1.2(\mathrm{SiMe})_{3}\right)$ ppm. Elemental Analysis: $\mathrm{C}_{26} \mathrm{H}_{58} \mathrm{~N}_{4} \mathrm{Si}_{2} \mathrm{Zn}$ (548.32): Calcd. (\%): C 56.95, H 10.66, N 10.22. Found (\%): C 56.68, H 10.39, N 9.81.

\subsection{Single-Crystal X-Ray Structure Determinations}

2.5a X-ray Crystallographic Analyses: Single crystals of compounds 1-3 were grown from diethyl ether at $-35^{\circ} \mathrm{C}$. In each case, a crystal of suitable dimensions was mounted on a CryoLoop (Hampton Research Corp) with a layer of light mineral oil, and placed in a nitrogen stream at 150(2) K. All measurements were made on an Agilent Supernova X-calibur Eos CCD detector with graphite-monochromatic Mo-K $\alpha(0.71069 \AA)$ radiation. Crystal data and structure refinement parameters are summarized in table 1 . The structures were solved by direct methods (SIR2004), ${ }^{20}$ and refined on $F^{2}$ by full-matrix least-squares methods using SHELXL-97. ${ }^{21}$ 
Table 1. Crystallographic details of 1-3.

\begin{tabular}{|c|c|c|c|}
\hline Complex & 1 & 2 & 3 \\
\hline CCDC No. & 1455627 & 1455625 & 1455626 \\
\hline Empirical formula & $\mathrm{C}_{34} \mathrm{H}_{66} \mathrm{~N}_{4} \mathrm{Si}_{2} \mathrm{Zn}$ & $\mathrm{C}_{22} \mathrm{H}_{50} \mathrm{~N}_{4} \mathrm{Si}_{2} \mathrm{Zn}$ & $\mathrm{C}_{26} \mathrm{H}_{58} \mathrm{~N}_{4} \mathrm{Si}_{2} \mathrm{Zn}$ \\
\hline Formula weight & 652.48 & 492.21 & 548.33 \\
\hline$T(\mathrm{~K})$ & 150 & 150 & 150 \\
\hline$\lambda(\AA)$ & 0.71073 & 0.71073 & 0.71073 \\
\hline Crystal system & Triclinic & Monoclinic & Monoclinic \\
\hline Space group & $P \overline{1}$ & $C 2 / c$ & $P 2_{1} / c$ \\
\hline$a(\AA)$ & $10.8269(7)$ & $17.3685(4))$ & $14.429(2)$ \\
\hline$b(\AA)$ & $10.8986(7)$ & $9.6045(2)$ & $9.3920(4)$ \\
\hline$c(\AA)$ & $17.4171(12)$ & $19.4893(5)$ & $25.500(13)$ \\
\hline$\alpha\left({ }^{\circ}\right)$ & $74.661(6)$ & 90 & 90 \\
\hline$\beta\left(^{\circ}\right)$ & $87.686(5)$ & $114.707(3)$ & 105.24(3) \\
\hline$\gamma\left({ }^{\circ}\right)$ & $74.820(5)$ & 90 & 90 \\
\hline$V\left(\AA^{3}\right)$ & $1911.9(2)$ & $2953.50(12)$ & $3334.2(17)$ \\
\hline $\mathrm{Z}$ & 2 & 4 & 4 \\
\hline$D_{\text {calc }} \mathrm{g} \mathrm{cm}^{-3}$ & 1.133 & 1.107 & 1.092 \\
\hline$\mu\left(\mathrm{mm}^{-1}\right)$ & 0.731 & 0.927 & 0.827 \\
\hline$F(000)$ & 712 & 1072 & 1200 \\
\hline Theta range for data collection & 3.07 to $29.10 \mathrm{deg}$. & 2.95 to $28.89 \mathrm{deg}$. & 2.86 to $29.01 \mathrm{deg}$. \\
\hline \multirow[t]{3}{*}{ Limiting indices } & $-14<=\mathrm{h}<=14$ & $-23<=\mathrm{h}<=11$ & $-18<=\mathrm{h}<=14$ \\
\hline & $-10<=\mathrm{k}<=14$ & $-12<=\mathrm{k}<=11$ & $-10<=\mathrm{k}<=12$ \\
\hline & $-15<=1<=23$ & $-17<=1<=25$ & $-32<=1<=31$ \\
\hline \multirow[t]{2}{*}{ Reflections collected / unique } & $16640 / 8720$ & $6405 / 3361$ & $16503 / 7718$ \\
\hline & {$[\mathrm{R}(\mathrm{int})=0.0414]$} & {$[\mathrm{R}(\mathrm{int})=0.0247]$} & {$[\mathrm{R}(\mathrm{int})=0.0260]$} \\
\hline Completeness to theta $=71.25$ & $99.8 \%$ & $99.8 \%$ & $99.8 \%$ \\
\hline Absorption correction & Multi-scan & Multi-scan & Multi-scan \\
\hline Max. and min. transmission & 1.000 and 0.99133 & 1.000 and 0.88467 & 1.000 and 0.94450 \\
\hline Refinement method & $\begin{array}{l}\text { Full-matrix least- } \\
\text { squares on } \mathrm{F}^{2}\end{array}$ & $\begin{array}{l}\text { Full-matrix least- } \\
\text { squares on } \mathrm{F}^{2}\end{array}$ & $\begin{array}{l}\text { Full-matrix least- } \\
\text { squares on } \mathrm{F}^{2}\end{array}$ \\
\hline Data / restraints / parameters & 8720 / 0 / 376 & $3361 / 0 / 139$ & $7718 / 0 / 316$ \\
\hline Goodness-of-fit on $\mathrm{F}^{2}$ & 1.040 & 1.038 & 1.034 \\
\hline Final $\mathrm{R}$ indices [I>2sigma(I)] & $\begin{array}{l}\mathrm{R} 1=0.0464 \\
\mathrm{wR} 2=0.0847\end{array}$ & $\begin{array}{l}\mathrm{R} 1=0.0320 \\
\mathrm{wR} 2=0.0684\end{array}$ & $\begin{array}{l}\mathrm{R} 1=0.0529 \\
\mathrm{wR} 2=0.1299\end{array}$ \\
\hline $\mathrm{R}$ indices (all data) & $\begin{array}{l}\mathrm{R} 1=0.0669 \\
\mathrm{wR} 2=0.0971\end{array}$ & $\begin{array}{l}\mathrm{R} 1=0.0409 \\
\mathrm{wR} 2=0.0732\end{array}$ & $\begin{array}{l}\mathrm{R} 1=0.0661 \\
\mathrm{wR} 2=0.1389\end{array}$ \\
\hline Largest diff. peak and hole & 0.346 and -0.362 e. $A^{-3}$ & 0.321 and $-0.242 \mathrm{e}^{-\mathrm{A}^{-3}}$ & 1.082 and -0.679 e. $\mathrm{A}^{-3}$ \\
\hline
\end{tabular}

Non-hydrogen atoms were anisotropically refined. Hatoms were included in the refinement on calculated positions riding on their carrier atoms. The function minimized was $\left[\sum w\left(F \mathrm{o}^{2}-F \mathrm{c}^{2}\right)^{2}\right]\left(w=1 /\left[\sigma^{2}\left(F \mathrm{o}^{2}\right)+\right.\right.$ $\left.\left.(a \mathrm{P})^{2}+b \mathrm{P}\right]\right)$, where $\mathrm{P}=\left(\operatorname{Max}\left(F \mathrm{o}^{2}, 0\right)+2 F \mathrm{c}^{2}\right) / 3$ with $\sigma^{2}\left(F \mathrm{O}^{2}\right)$ was derived from counting statistics. The function $R 1$ and $w R 2$ are $\left(\Sigma\left\|F_{\mathrm{O}}|-| F \mathrm{c}\right\|\right) / \Sigma\left|F_{\mathrm{O}}\right|$ and $\left[\Sigma w\left(F \mathrm{o}^{2}-F \mathrm{c}^{2}\right)^{2} / \Sigma\left(w F \mathrm{o}^{4}\right)\right]^{1 / 2}$, respectively. The ORTEP-3 program ${ }^{22}$ was used to draw the molecule. Crystallographic data (excluding structure factors) for the structures reported in this paper have been deposited with the Cambridge Crystallographic<smiles>[R]N=C(CCCCCCC)N[R]</smiles>

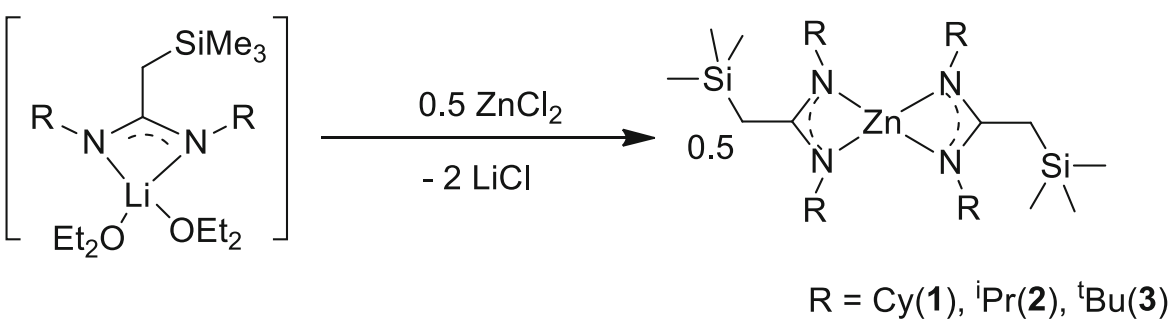

Scheme 1. Synthesis of zinc complexes 1-3. 
Data Centre as supplementary publication no. CCDC 1455625-1455627. Copies of the data can be obtained free of charge on application to CCDC, 12 Union Road, Cambridge CB21EZ, UK (fax: + (44)1223-336-033; email: deposit@ccdc.cam.ac.uk).

\section{Results and Discussion}

\subsection{Syntheses of complexes 1-3}

Three homoleptic zinc amidinato complexes of molecular formulas $\left[\mathrm{Zn}\left\{\mathrm{CyN}=\mathrm{C}\left(\mathrm{CH}_{2} \mathrm{SiMe}_{3}\right) \mathrm{NCy}\right\}_{2}\right]$ (1), $\left[\mathrm{Zn}\left\{{ }^{i} \mathrm{PrN}=\mathrm{C}\left(\mathrm{CH}_{2} \mathrm{SiMe}_{3}\right) \mathrm{N}^{i} \mathrm{Pr}\right\}_{2}\right]$ (2) and $\left[\mathrm{Zn}\left\{{ }^{t} \mathrm{BuN}=\right.\right.$ $\left.\mathrm{C}\left(\mathrm{CH}_{2} \mathrm{SiMe}_{3}\right) \mathrm{N}^{t} \mathrm{Bu}\right\}_{2}$ ] (3) were obtained by one-pot reactions of respective carbodiimides with neosilyllithium $\left(\mathrm{LiCH}_{2} \mathrm{SiMe}_{3}\right)$ followed by the addition of anhydrous $\mathrm{ZnCl}_{2}$ in a 2:2:1 molar ratio in diethyl ether at room temperature (scheme 1). It is believed that reaction of carbodiimides and neosilyllithium generated lithium amidinates of molecular formula $\left[\left(\mathrm{Et}_{2} \mathrm{O}\right)_{2}\right.$ $\left.\mathrm{Li}\left\{\mathrm{RN}=\mathrm{C}\left(\mathrm{CH}_{2} \mathrm{SiMe}_{3}\right) \mathrm{NR}\right\}_{2}\right]$. The reaction of metal alkyl or metal amides towards carbodiimides have recently been reported by us and others too. ${ }^{23}$ Respective zinc amidinate complexes were obtained (scheme 1) following the subsequent reaction of lithium amidinates with anhydrous zinc chloride. All complexes were synthesized in pure form and obtained in good yields through re-crystallization from diethyl ether at $-35^{\circ} \mathrm{C}$. All the new zinc complexes 1-3 were characterized using standard analytical and spectroscopic techniques. The solid-state structures of all three complexes were established by single-crystal X-ray diffraction analysis.

In the ${ }^{1} \mathrm{H}$ NMR spectra measured in $\mathrm{C}_{6} \mathrm{D}_{6}$, all complexes (1-3) exhibited one set of signals in the solution state. A sharp singlet resonance at $\delta 1.91$ (for complex 1), 1.85 (for complex 2) and $2.20 \mathrm{ppm}$ (for complex 3) can be assigned to the methylene protons present in the neosilyl group $\left(\mathrm{CH}_{2}-\mathrm{SiMe}_{3}\right)$ attached to the amidinate ligands. The resonance signals for the corresponding cyclohexyl moieties were in the expected region for complex $\mathbf{1}$, and well in agreement with literature values. ${ }^{8}$ A septet signal centred at $\delta 3.50 \mathrm{ppm}$, and a doublet signal centered at $\delta 1.19$ were observed for the four isopropyl protons and corresponding eight methyl protons present in complex 2 . However, a sharp singlet in each complex appeared at $\delta 0.18$ (1), 0.14 (2) and $0.24(3) \mathrm{ppm}$ due to the resonances of $\mathrm{SiMe}_{3}$ protons. In addition, a sharp singlet resonance at $\delta 1.38$ ppm was observed for the methyl protons of tert-butyl group present in complex 3. In ${ }^{13} \mathrm{C}\left\{{ }^{1} \mathrm{H}\right\} \mathrm{NMR}$, spectra of complexes 1-3 are similar, and the signals at $\delta 171.4$ (for 1), 173.3 (for 2) and 171.9 (for 3) ppm indicate the presence of $s p^{2}$ carbon $\left(-\mathrm{N}-C\left(\mathrm{CH}_{2} \mathrm{SiMe}_{3}\right)=\mathrm{N}-\right)$ in all

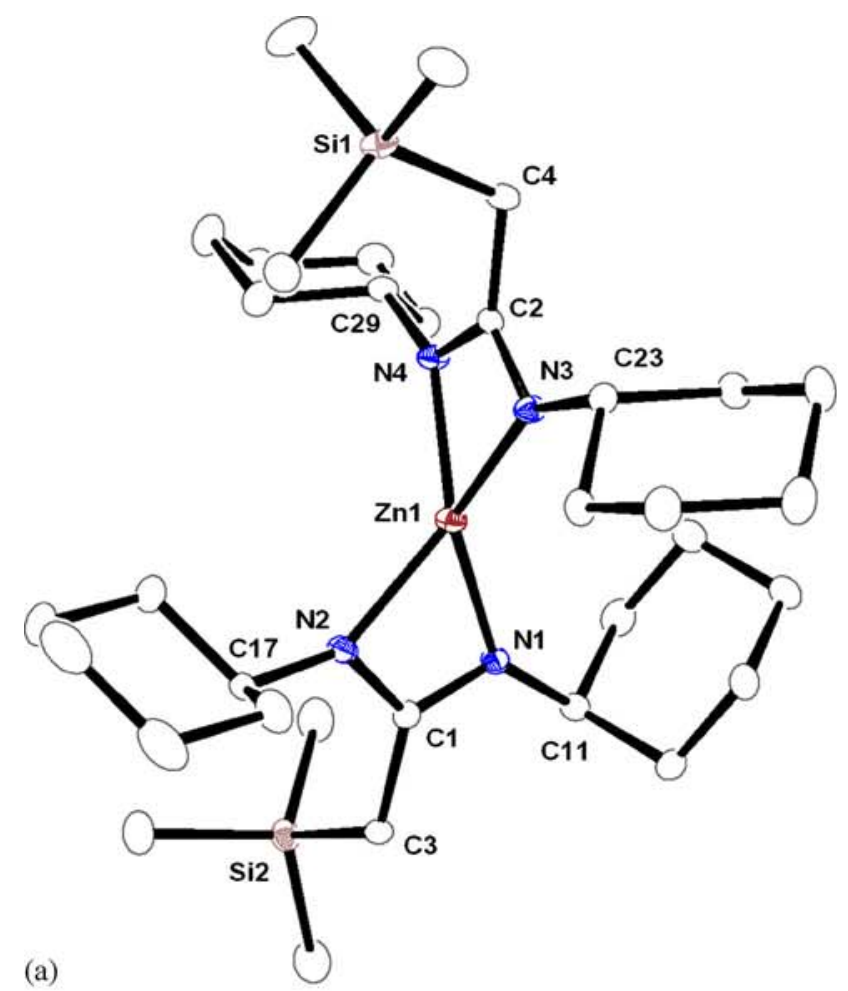

(b)
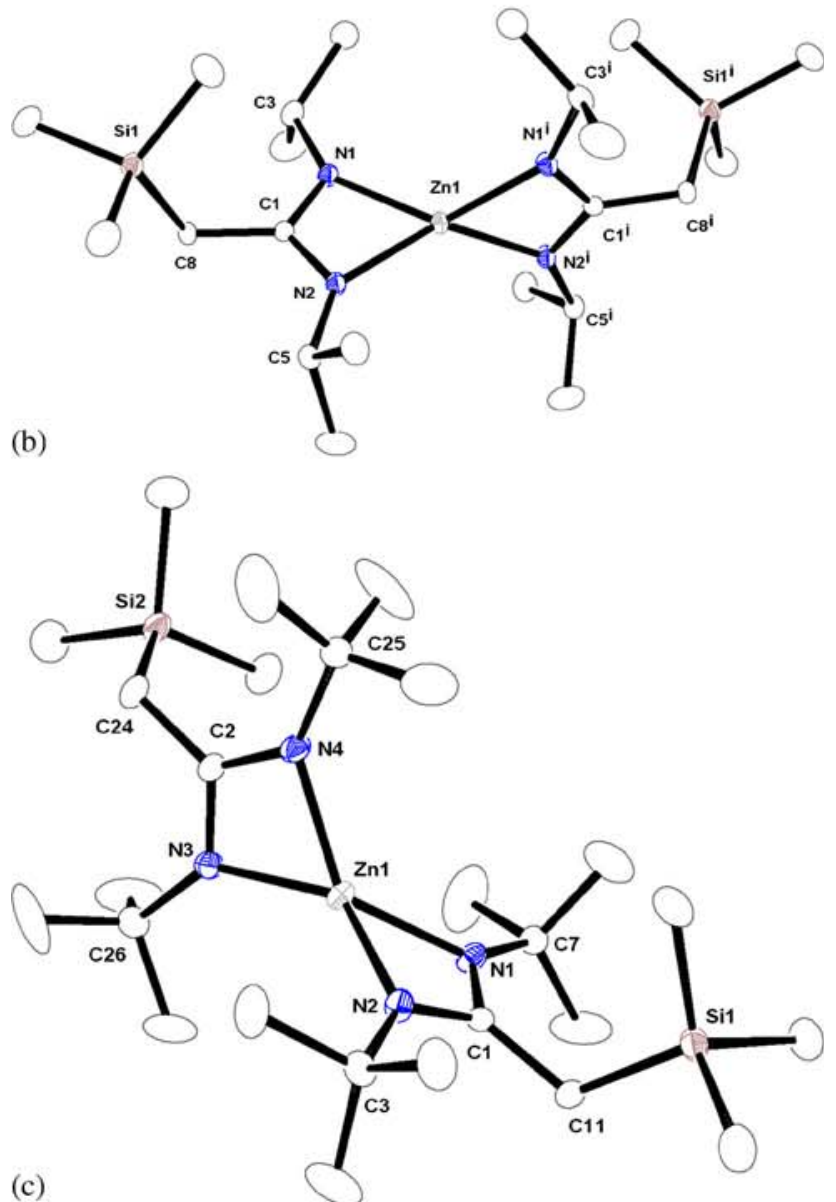

(c)

Figure 1. Solid state structures of compound 1 (top), 2 (middle) and $\mathbf{3}$ (bottom). Ellipsoids are drawn to encompass $30 \%$ probability. Selected bond lengths and bond angles are given in table 2 . 
complexes. Solid state structures of all the complexes (1-3) were determined by single crystal X-ray diffraction analysis.

\subsection{Molecular Structures of complexes 1-3}

The molecular structures of complexes 1-3 in the solid state confirmed the attachment of amidinate ligand to the zinc ion. It was observed that complex 1 crystallizes in the triclinic space group $P-1$ having two independent molecules in the unit cell. In contrast, complexes 2 and 3 crystallize in the monoclinic space group $P 2 / \mathrm{c}$ having four individual molecules of $\mathbf{2}$ and $\mathbf{3}$ in their respective unit cells. The details of their structural parameters are given in table 1 . The solid state structures of complexes 1-3 are presented in figure 1 . Selected bond lengths and bond angles are given in table 2. All the complexes are homoleptic and monomeric in nature, and their structural parameters are similar. All $\mathrm{Zn}-\mathrm{N}$ bond distances Zn1-N1 2.0215 (2), Zn1-N2 2.0195 (2), Zn1-N3 2.0138 (2) and Zn1-N4 2.0208 (2) for 1, Zn1-N1 2.0231 (1), Zn1-N2 2.0168 (1), Zn1-N1 2.0231 (1) and Zn1$\mathrm{N} 2{ }^{\mathrm{i}} 2.0168$ (1) for 2, and Zn1-N1 2.018 (2), Zn1-N2 2.011 (2), Zn1-N3 2.012 (2) and Zn1-N4 2.016 (2) for 3 are in the same range, thus indicating complete delocalization of negative charge over the $\mathrm{N}-\mathrm{C}-\mathrm{N}$ skeletons in each complex. This observation is further evidenced by the having comparable $\mathrm{N}-\mathrm{C}$ bond lengths (in $\AA$ ), N1-C1 1.335 (3), N2-C1 1.328 (3) for 1, N1-C1 1.330 (2), N2-C1 1.328 (2) for 2, and N1-C1 1.337 (3), N2C1 1.326 (3) for $\mathbf{3}$, respectively. In each complex, the geometry of each zinc ion can be best described as dis-

Table 2. Selected bond lengths $[\AA]$ and bond angles $\left[^{\circ}\right]$.

\begin{tabular}{|c|c|c|}
\hline 1 & 2 & 3 \\
\hline Zn1-N1 2.0215(2) & Zn1-N1 2.0231(1) & Zn1-N1 2.018(2) \\
\hline Zn1-N2 2.0195(2) & Zn1-N2 2.0168(1) & $\mathrm{Zn} 1-\mathrm{N} 22.011(2)$ \\
\hline Zn1-N3 2.0138(2) & $\mathrm{Zn} 1-\mathrm{N} 1^{\mathrm{i}} 2.0231(1)$ & Zn1-N3 2.012(2) \\
\hline Zn1-N4 2.0208(2) & Zn1-N2i $2.0168(1)$ & Zn1-N4 2.016(2) \\
\hline Zn1-C1 2.440(2) & Zn1-C1 2.4449(2) & Zn1-C1 2.460(3) \\
\hline Zn1-C2 2.442(2) & $\mathrm{Zn} 1-\mathrm{C} 1^{\mathrm{i}} 2.4449(2)$ & $\mathrm{Zn} 1-\mathrm{C} 22.462(3)$ \\
\hline N1-C1 1.335(3) & $\mathrm{N} 1-\mathrm{C} 11.330(2)$ & $\mathrm{N} 1-\mathrm{C} 11.337(3)$ \\
\hline N2-C1 1.328(3) & N2-C1 1.328(2) & N2-C1 1.336(3) \\
\hline N3-C2 1.337(3) & $\mathrm{C} 1-\mathrm{C} 81.503(2)$ & N2-C3 1.470(3) \\
\hline N4-C2 1.331(3) & N2-Zn1-N2 ${ }^{\mathrm{i}} 136.44(8)$ & N3-C2 1.343(3), \\
\hline C1-C3 1.504(3) & $\mathrm{N} 1-Z n 1-\mathrm{N} 1^{\mathrm{i}} 135.70(6) \mathrm{N} 2^{\mathrm{i}}-$ & N4-C2 1.338(4) \\
\hline C2-C4 1.500(3) & $\mathrm{Zn} 1-\mathrm{N} 1^{\mathrm{i}} 65.84(5)$ & $\mathrm{C} 1-\mathrm{C} 11$ 1.513(4) \\
\hline N2-Zn1-N4 134.28(7) & N2-Zn1-N1 65.84(5) & C2-C24 1.513(4) \\
\hline N3-Zn1-N2 132.47(8) & 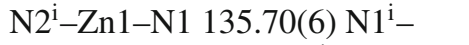 & C3-C4 1.512(5) \\
\hline N3-Zn1-N4 66.18(7) & Zn1-N1 131.22(8) N2i $-\mathrm{Zn} 1-\mathrm{C} 1$ & N2-Zn1-N3 137.09(9) \\
\hline N3-Zn1-N1 135.19(7) & 149.30(5) N1 $1^{\mathrm{i}}-\mathrm{Zn} 1-\mathrm{C} 1$ & N2-Zn1-N4 134.93(1) \\
\hline N2-Zn1-N1 66.11(8), & 144.76(5) N2-Zn1-C1 $1^{\mathrm{i}}$ & N3-Zn1-N4 65.92(1) \\
\hline N4-Zn1-N1 136.38(8) & $149.30(5) \mathrm{N} 1-\mathrm{Zn} 1-\mathrm{C} 1^{\mathrm{i}}$ & N2-Zn1-N1 65.72(9) \\
\hline C1-N1-Zn1 90.91(1) & $144.76(5) \mathrm{C} 1-\mathrm{Zn} 1-\mathrm{C} 1^{\mathrm{i}}$ & N3-Zn1-N1 134.78(1) \\
\hline C1-N2-Zn1 91.21(1) & 176.89(7) C1-N1-C3 125.50(1) & N4-Zn1-N1 132.31(1) \\
\hline C2-N3-Zn1 91.28(1) & C1-N1-Zn1 91.22(1) & N3-Zn1-C1 149.32(9) \\
\hline C2-N4-Zn1 91.13(1) & C3-N1-Zn1 143.28(1) & N4-Zn1-C1 144.66(9) \\
\hline N2-C1-N1 111.73(2) & C1-N2-Zn1 91.57(1) & N2-Zn1-C2 149.15(9) \\
\hline N2-C1-C3 124.6(2) & C5-N2-Zn1 141.96(1) & N1-Zn1-C1 145.03(9) \\
\hline N1-C1-C3 123.5(2) & N2-C1-N1 111.37(1) & C1-Zn1-C2 176.85(8) \\
\hline C3-C1-Zn1 177.85(2) & C8-C1-Zn1 177.68(1). & C1-N1-Zn1 92.06(2) \\
\hline N4-C2-N3 111.30(2) & & C1-N2-Zn1 92.41(2) \\
\hline N4-C2-C4 125.00(2) & & C2-N3-Zn1 92.23(2) \\
\hline N3-C2-C4 123.47(2) & & C2-N4-Zn1 92.17(2) \\
\hline \multirow[t]{7}{*}{ C4-C2-Zn1 173.05(2) } & & N2-C1-N1 109.8(2) \\
\hline & & N2-C1-C11 124.1(2) \\
\hline & & N1-C1-C11 126.1(2) \\
\hline & & C11-C1-Zn1 177.36(2) \\
\hline & & N4-C2-N3 109.7(2) \\
\hline & & N4-C2-C24 126.0(2) \\
\hline & & N3-C2-C24 124.3(3). \\
\hline
\end{tabular}


torted tetrahedral which is commonly observed in zinc chemistry as reported in literature. ${ }^{8}$ In each case, two four-membered zinc metallacycles, Zn1-N1-C1-N2 and Zn1-N3-C2-N4, could be observed due to the bidentate coordination mode of two amidinato ligands to the zinc metal ion in each complex (1-3). Two planes having N1, $\mathrm{C} 1, \mathrm{~N} 2, \mathrm{Zn} 1$, and N3, C2, N4 and Zn1 are orthogonal (dihedral angles $89.51^{\circ}$ for $1 ; 87.59^{\circ}$ for 2 and $89.70^{\circ}$ ) to each other and thereby indicating no influence on amidinato nitrogen atoms from the alkyl substituents.

\section{Conclusions}

In summary, we have successfully demonstrated a one-pot synthesis and structural characterization of homoleptic zinc amidinate complexes using three different carbodiimides. This method can be used to prepare amidinate moities from easily available carbodiimides. From their molecular structures in the solid state, we have observed that all the zinc complexes are homoleptic with similar structural parameters, thus resulting in the adoption of a distorted tetrahedral geometry around the zinc ion.

\section{Supplementary Information (SI)}

The ${ }^{1} \mathrm{H}$ and ${ }^{13} \mathrm{C}\left\{{ }^{1} \mathrm{H}\right\}$ NMR spectra of complexes 1-3 are given in Supplementary Information, available at www. ias.ac.in/chemsci.

\section{Acknowledgements}

This work is supported by the Ministry of New and Renewable Energy (MNRE), India, under Project No. $103 / 209 / 2013-N T$, dated $29^{\text {th }}$ September, 2014. The instrumental facilities were provided by the Indian Institute of Technology Hyderabad (IITH). S.A. thanks CSIR, India, for his PhD fellowship.

\section{References}

1. Prince R H 1979 Adv. Inorg. Chem. Radiochem. 22349

2. Uchiyama M, Furumoto S, Saito M, Kondo Y and Sakamoto T 1997 J. Am. Chem. Soc. 11911425

3. Uchiyama M, Nakamura S, Ohwada T, Nakamura M and Nakamura E 2004 J. Am. Chem. Soc. 12610897

4. Bourget-Merle L, Lappert M F and Severn J R 2002 Chem. Rev. 1023031

5. Bailey P J and Pace S 2001 Coord. Chem. Rev. 21491

6. Barker J and Kilner M 1994 Coord. Chem. Rev. 133219

7. Coles M P 2006 J. Chem. Soc. Dalton Trans. 985
8. (a) Schmidt S, Schulz S, Bläser D, Boese R and Bolte M 2010 Organometallics 29 6097; (b) Eisenmann T, Khanderi J, Schulz S and Flörke U 2008 Z. Anorg. Allg. Chem. 634 507; (c) Münch M, Flörke U, Bolte M, Schulz S and Gudat D 2008 Angew. Chem. Int. Ed. 47 1512; (d) Coles M P and Hitchcock P B 2004 Eur. J. Inorg. Chem. 2662; (e) Schmidt S, Gutschank B, Schulz S, Bläser D, Boese R and Wölper C 2011 Eur. J. Inorg. Chem. 4464; (f) Marks S, Köppe R, Panda T K and Roesky P W 2010 Chem. Eur. J. 16 7096; (g) Mark S, Panda T K and Roesky P W 2010 Dalton Trans. 7230

9. (a) Prust J, Stasch A, Zheng W, Roesky H W, Alexopoulos E, Usón I, Böhler D and Schuchardt T 2001 Organometallics 20 3825; (b) Prust J, Hohmeister H, Stasch A, Roesky H W, Magull J, Alexopoulos E, Usón I, Schmidt H-G and Noltemeyer M 2002 Eur. J. Inorg. Chem. 2157; (c) Aboulkacem S, Tyrra W and Pantenburg I 2003Z. Anorg. Allg. Chem. 6291569

10. (a) Cheng M, Attygalle A B, Lobkovsky E B and Coates G W 1999 J. Am. Chem. Soc. 121 11583; (b) Chamberlain B M, Cheng M, Moore D R, Ovitt T M, Lobkovsky E B and Coates G W $2001 \mathrm{~J}$. Am. Chem. Soc. 123 3229; (c) Chisholm M H, Huffman J C, Phomphrai K, Cheng M, Attygalle A B, Lobkovsky E B and Coates G W1999 J. Chem. Soc. Dalton Trans. 222; (d) Allen S D, Moore D R, Lobkovsky E B and Coates G W 2003 J. Organomet. Chem. 683 137; (e) Allen S D, Moore D R, Lobkovsky E B and Coates G W 2002 J. Am. Chem. Soc. 124 14284; (f) Chisholm M H, Gallucci J C and Phomphrai K 2005 Inorg. Chem. 448004

11. (a) Allen S D, Moore D R, Lobkovsky E B and Coates G W 2002 J. Am. Chem. Soc. 124 14284; (b) Liu B Y, Tian C Y, Zhanq L, Yan W D and Zhanq W J 2006 J. Polym. Sci. Part A: Polym. Chem. 44 6243; (c) Kröger M, Folli C, Walter O and Döring M 2006 Adv. Synth. Cat. 348 1908; (d) Cheng M, Moore D R, Reczek J J, Chamberlain B M, Lobkovsky E B and Coates G W 2001 J. Am. Chem. Soc. 1238738

12. (a) Resa I, Carmona E, Gutierrez-Puebla E and Monge A 2004 Science 305 1136; (b) del Río D, Galindo A, Resa I and Carmona E 2005 Angew. Chem. 117 1270; (c) del Río D, Galindo A, Resa I and Carmona E 2005 Angew. Chem. Int. Ed. 441244

13. Wang Y, Quillian B, Wei P, Wang H, Yang X-J, Xie Y, King R B, Schleyer P v R, Schaefer H F III and Robinson G H 2005 J. Am. Chem. Soc. 12711944

14. Fedushkin I L, Skatova A A, Ketkov S Y, Eremenko O V, Piskunov A V and Fukin G H 2007 Angew. Chem. 119 4380; 2007 Angew. Chem. Int. Ed. 464302

15. (a) Edelmann FT 2103 Adv. Organomet. Chem. 61 55; (b) Baunemann A, Bekermann D, Thiede T B, Parala H, Winter M, Gemel C and Fischer R A 2008 Dalton Trans. 3715; (c) Coyle J P, Monillas W H, Yap G P A and Barry S T 2011 Eur. J. Inorg. Chem. 4464; (d) Brazeau A L and Barry S T 2008 Chem. Mater. 20 7287; (e) Coyle J P, Johnson P A, DiLabio G A, Barry S T and Müller J 2010 Inorg. Chem. 49 2844; (f) Wasslen Y A, Tois E, Haukka S, Kreisel K A, Yap G P A, Halls M D and Barry S T 2010 Inorg. Chem. 491976

16. (a) Suresh P and Prabusankar G 2014 J. Chem. Sci. 126 1409; (b) Tripathi S, Srirambalaji R, Singh N 
and Anantharaman G 2014 J. Chem. Sci. 126 1423; (c) Vishnoi P, Ch Kalita A and Murugavel R 2014 J. Chem. Sci. 126 1385; (d) Mudsainiya R K, Jassala M K, Arora M and Chawla S K 2015 J. Chem. Sci. 127849

17. (a) Anga S, Rej S, Naktode K, Pal T and Panda T K 2105 J. Chem. Sci. 127 103; (b) Anga S, Pal T, Kottalanka R K, Paul M and Panda T K 2013 Can. Chem. Trans. 1105

18. Naktode K, Anga S, Kottalanka R K, Nayek H P and Panda T K 2014 J. Coord. Chem. 67236

19. Vaughn G D, Krein K A and Gladysz J A 1986 Organometallics 5936
20. Burla M C, Caliandro R, Camalli M, Carrozzini B, Cascarano G L, De Caro L, Giacovazzo C, Polidoria G and Spagna R 2005 J. Appl. Cryst. 38381

21. Sheldrick G M 1997 SHELXL-97 Program of Crystal Structure Refinement (University of Göttingen: Göttingen, Germany)

22. Farrugia L J 1999 J. Appl. Cryst. 32837

23. (a) Panda $\mathrm{T} \mathrm{K}$, Tsurugi $\mathrm{H}$, Pal K, Kaneko $\mathrm{H}$ and Mashima K 2010 Organometallics 29 34; (b) Naktode K, Das S, Bhattacharjee J, Nayek H P and Panda T K 2016 Inorg. Chem. 55 1142; (c) Michel O, Meermann C, Törnroos K W and Anwander R 2009 Organometallics 284783 